\title{
Identification of phlebotomine sand fly blood meals by real-time PCR
}

\author{
Kamila Gaudêncio da Silva Sales ${ }^{1}$, Pietra Lemos Costa ${ }^{1}$, Rayana Carla Silva de Morais ${ }^{1}$, Domenico Otranto ${ }^{2}$, \\ Sinval Pinto Brandão-Filho ${ }^{1}$, Milena de Paiva Cavalcanti ${ }^{1}$ and Filipe Dantas-Torres ${ }^{1,2^{*}}$
}

\begin{abstract}
Background: Phlebotomine sand flies are blood-feeding insects of great medical and veterinary significance acting as vectors of Leishmania parasites. Studying the blood-feeding pattern of these insects may help in the understanding of their interactions with potential reservoir hosts of Leishmania parasites. In this study, we developed real time PCR assays for the identification of sand fly blood meal.

Methods: Six pairs of primers were designed based on cytochrome $b$ gene sequences available in GenBank of the following potential hosts: dog, cat, horse, chicken, black rat, and human. Firstly, SYBR Green-based real time PCR assays were conducted using a standard curve with eight different concentrations (i.e., 10 ng, 1 ng, 100 pg, 10 pg, 1 pg, 100 fg, $10 \mathrm{fg}$ and $1 \mathrm{fg}$ per $2 \mu \mathrm{ll}$ ) of DNA samples extracted from EDTA blood samples from each target animal. Then, DNA samples extracted from field-collected engorged female sand flies belonging to three species (i.e., Lutzomyia longipalpis, L. migonei and $L$. lenti) were tested by the protocols standardized herein. Additionally, female sand flies were experimentally fed on a black rat (Rattus rattus) and used for evaluating the time course of the detection of the protocol targeting this species.

Results: The protocols performed well with detection limits of $10 \mathrm{pg}$ to $100 \mathrm{fg}$. Field-collected female sand flies were fed on blood from humans (73\%), chickens (23\%), dogs (22\%), horses (15\%), black rats (11\%) and cats (2\%). Interestingly, $76.1 \%$ of the L. longipalpis females were positive for human blood. In total, $48 \%$ of the tested females were fed on single sources, $31 \%$ on two and $12 \%$ on three. The analysis of the time course showed that the real time PCR protocol targeting the black rat DNA was able to detect small amounts of the host DNA up to 5 days after the blood meal.

Conclusions: The real time PCR assays standardized herein successfully detected small amounts of host DNA in female sand flies fed on different vertebrate species and, specifically for the black rats, up to 5 days after the blood meal. These assays represent promising tools for the identification of blood meal in field-collected female sand flies.
\end{abstract}

Keywords: Phlebotomine sand flies, Blood meal, Brazil, Real time PCR

\section{Background}

Phlebotomine sand flies are blood-feeding insects of great medical and veterinary significance, due to their ability to transmit bacteria, virus, and protozoa to humans and animals [1]. Indeed, besides water and carbohydrates for flight and general metabolism, female sand flies almost always need to take a blood meal for the protein supplementation for egg production [2]. While the preference of certain species of sand flies for a given animal species or group (e.g., mammals or birds)

\footnotetext{
*Correspondence: filipe.dantas@cpqam.fiocruz.br

'Department of Immunology, Centro de Pesquisas Aggeu Magalhães,

Fundação Oswaldo Cruz, Recife, Pernambuco 50740-465, Brazil

2Department of Veterinary Medicine, Università degli Studi di Bari, Valenzano, Bari 70010, Italy
}

\section{Biomed Central}

(C) 2015 Sales et al.; licensee BioMed Central. This is an Open Access article distributed under the terms of the Creative Commons Attribution License (http://creativecommons.org/licenses/by/4.0), which permits unrestricted use, distribution, and reproduction in any medium, provided the original work is properly credited. The Creative Commons Public Domain Dedication waiver (http://creativecommons.org/publicdomain/zero/1.0/) applies to the data made available in this article unless otherwise stated. may vary widely, the selective behaviour of some species has been acknowledged. For instance, in a study conducted in Belém (Pará, Brazil), Lutzomyia flaviscutellata was the predominant species reported to bite rodents [3]. Nonetheless, most sand fly species for which information is available appear to be generalists rather than specialists in their host range [4-8]. This is the case of Lutzomyia longipalpis, the most important vector of Leishmania infantum in the Americas [9], making the host choice a matter of availability rather than preference. Understanding the blood-feeding patterns of these insects is of great ecological and epidemiological relevance, as it may provide date on host use and on potential reservoirs of Leishmania spp. [10]. 
Different methods have been traditionally applied to study the blood-feeding behaviour of sand flies, including the precipitin test [4,7,11-13] and ELISA [14-16]. However, these methods present some technical limitations (e.g., the possibility of cross-reactivity between species, the need for producing specific antibodies to several species, and the inability to discover unpredicted hosts) ([10]; and references cited therein).

In light of these limitations, molecular methods have been developed for arthropod blood meal identification, including DNA sequencing, group-specific polymerase chain reaction primers, restriction fragment length polymorphism, real-time polymerase chain reaction, heteroduplex analysis, reverse line-blot hybridization and DNA profiling (reviewed in [17]). Incidentally, several genetic markers have been employed including mitochondrial genes (e.g., cytochrome $b$ and cytochrome $c$ oxidase subunit I genes), ribosomal RNA genes (e.g., $12 \mathrm{~S}$ and $16 \mathrm{~S}$ rDNA) and a nuclear gene (e.g., prepronociceptin gene) [17].

In the present study, we developed six uniplex SYBR Green-based real time PCR assays for sand fly blood meal identification using cytochrome $b$ as a genetic target. These assays enable the detection of small quantities of the host DNA and represent new tools for the study of vector-host interactions.

\section{Methods}

\section{Blood samples and sand flies}

Blood samples from potential sand fly blood sources (i.e., dog, cat, horse, chicken, black rat, and human) were used as standard DNA. Moreover, a group of female sand flies were experimentally fed on a black rat (Rattus rattus) and used for evaluating the detection capacity of the assay targeting this species in function of time (see below).

Out of 24,226 sand flies collected in the framework of a previous study [18], 100 engorged females (92 L. longipalpis, seven Lutzomyia migonei and one Lutzomyia lenti) were used as field samples. In brief, these females were collected from August 2009 to August 2010, using standard CDC light traps in chicken coops, corrals and other animal sheds near human houses in the municipality of Passira $\left(07^{\circ} 59^{\prime} 42^{\prime \prime}\right.$ S, $35^{\circ} 34^{\prime} 51^{\prime \prime}$ O), Pernambuco, northeastern Brazil [18]. In the laboratory, these females were dissected and both head and the last three abdominal segments were used for species identification [19]. The thorax and remaining part of the abdomen of each female were transferred to a $1.5 \mathrm{ml}$ tube and stored at $-20^{\circ} \mathrm{C}$ for molecular processing.

\section{DNA extraction and quality assessment}

Genomic DNA was extracted from female sand flies and animal blood using DNeasy Blood \& Tissue kit and QIAamp DNA Blood Mini Kit (Qiagen), respectively. Purified DNA samples were eluted in $100 \mu \mathrm{l}$ of Tris-
EDTA buffer and frozen at $-80^{\circ} \mathrm{C}$. The quantity and degree of purity of the DNA samples was assessed using a Nanodrop 2000c spectrophotometer (Thermo Scientific).

\section{Primer designing and real time PCR conditions}

Primers targeting each host species (i.e., dog, cat, horse, chicken, black rat, and human) were designed based on cytochrome $b$ gene sequences available in GenBank (Table 1), using Primer BLAST (http://www.ncbi.nlm. nih.gov/tools/primer-blast), considering the following criteria: expected PCR product size (70-120 base pairs) and primer melting temperatures $\left(57-63^{\circ} \mathrm{C}\right)$.

DNA-free water was used as no template control (NTC) and unengorged females as negative control. The uniplex real time PCR reactions were run in an $\mathrm{ABI}$ PRISM $7000^{\circ}$ (Applied Biosystems) and the results analyzed using 7500 software v2.3 (Applied Biosystems). Initially, each reaction consisted of a final volume of $50 \mu \mathrm{l}$ containing $21 \mu \mathrm{l}$ of type 1 water, $1 \mu \mathrm{l}$ of each primer (5 pmol), $25 \mu \mathrm{l}$ of SYBR Green-PCR Master Mix (Applied Biosystems) and $2 \mu \mathrm{l}$ of DNA template. Some reactions were also done in a final volume of $25 \mu$ li.e., $8.5 \mu \mathrm{l}$ of type 1 water, $1 \mu \mathrm{l}$ of each primer $(5 \mathrm{pmol}), 12.5 \mu \mathrm{l}$ of SYBR Green-PCR Master Mix and $2 \mu \mathrm{l}$ of DNA template), with no differences in terms of efficiency (data not shown). PCR conditions were: initial denaturation at $95^{\circ} \mathrm{C}$ for $10 \mathrm{~min}$, then 40 cycles at $95^{\circ} \mathrm{C}$ for $15 \mathrm{~s}$ and at $60^{\circ} \mathrm{C}$ for $1 \mathrm{~min}$. All samples were tested in duplicate. The cutoff point was defined as the $\mathrm{Ct}$ value that corresponds to the defined lower limit of detection of the assay and, any $\mathrm{Ct}$ value above this limit, was considered negative.

\section{Efficiency, specificity, detection limit and time course detection}

The amplification efficiency $(\varepsilon)$ was calculated using the equation: $\varepsilon=10^{(-1 / \text { slope })}-1$ [20]. In the same way, the specificity $(\sigma)$ of the assays was determined by using primers for one animal species (target) and DNA from another animal species (templates), being calculated using the equation: $\sigma=(1+\varepsilon)^{\Delta \mathrm{Ct}}$; where $\Delta \mathrm{Ct}$ is the difference in the $\mathrm{Ct}$ values of the defined target and the templates. Melt curve was also considered in the specificity analysis. The detection limit of the assays was assessed using 10-fold serial dilutions (10 ng, $1 \mathrm{ng}$, $100 \mathrm{pg}, 10 \mathrm{pg}, 1 \mathrm{pg}, 100 \mathrm{fg}, 10 \mathrm{fg}$, and $1 \mathrm{fg}$ per $2 \mu \mathrm{l}$ ) of genomic DNA from each animal species. Finally, time course experiments were carried out to determine how long the host DNA could remain detectable by real time PCR. In particular, sand flies $(n=50)$ fed on a black rat were kept in the laboratory for different periods of time (i.e., 1 h, 24 h, 48 h, 72 h, 96 h, 120 h, and 142 h) after the blood meal ingestion. At each time point five female sand flies were taken and subjected to DNA extraction or kept at $-20^{\circ} \mathrm{C}$ until processing. 
Table 1 Primers targeting host cytochrome $b$ gene

\begin{tabular}{|c|c|c|c|c|}
\hline Host species & Primers & CG content & $\operatorname{Tm}\left({ }^{\circ} \mathrm{C}\right)$ & Product size (bp) \\
\hline \multirow[t]{2}{*}{ Canis lupus familiaris } & f5' - AGCGCCGTCTAACATCTCTG - 3' & 55.45 & 55.90 & 118 \\
\hline & r5' - TGTGGCTGTGTCCGATGTAT - 3' & 50.89 & 59.10 & \\
\hline \multirow[t]{2}{*}{ Equus caballus } & f5' - CAGCCAGTGGAACACCCATA- 3' & 55.00 & 59.67 & 103 \\
\hline & r5' - TGTTITCGATGGTGCTTGCG - 3' & 50.00 & 60.04 & \\
\hline \multirow[t]{2}{*}{ Felis catus } & f5' - AGAATGGATCTGAGGGGGCT - 3' & 55.00 & 60.03 & 108 \\
\hline & r5' - AGGTGTACTGCTGCTAAGGC - 3' & 55.00 & 59.75 & \\
\hline \multirow[t]{2}{*}{ Gallus gallus } & f5' - CAGCAGACACATCCCTAGCC - 3' & 60.00 & 60.18 & 104 \\
\hline & r5' - GAAGAATGAGGCGCCGTTTG - 3' & 55.00 & 60.18 & \\
\hline \multirow[t]{2}{*}{ Homo sapiens } & f5' - AGGCGTCCTTGCCCTATTAC- 3' & 55.00 & 59.53 & 104 \\
\hline & r5' - GTGATTGGCTTAGTGGGCG - 3' & 55.00 & 60.39 & \\
\hline \multirow[t]{2}{*}{ Rattus rattus } & f5' - GAATTGGGGGCCAACCAGTA - 3' & 55.00 & 59.00 & 109 \\
\hline & r5' - TCAATGATTCCGGAGATTGGT - 3' & 42.86 & 57.00 & \\
\hline
\end{tabular}

CG content: guanine-cytosine content; Tm: melting temperature.

\section{DNA sequencing and analysis}

PCR products were purified using Pure Link PCR Purification (Invitrogen), sequenced using a Big Dye Terminator v3.1 Cycle Sequencing and analyzed ABI 3100 Genetic Analyzer (Applied Biosystems). Sequences generated were compared with known sequences available in the National Center for Biotechnology Information GenBank by using the Basic Local Alignment Search Tool algorithm (http://www.ncbi.nlm.nih.gov/BLAST).

\section{Ethical considerations}

All the procedures adopted in this study were approved by the human and animal ethics committees of the Centro de Pesquisas Aggeu Magalhães, Oswaldo Cruz Foundation,
Recife, Pernambuco, Brazil (CPqAM: CEP 14/13 and CEUA 55/2013).

\section{Results}

Each real time PCR protocol amplified successfully the DNA of the target animal species (Figure 1). No amplification was obtained with NTC or with negative controls (unengorged females). Non-specific amplification occurred in some cases: the primers targeting chickens amplified human (Ct 36.2-37.9) and black rat (Ct 37.6); the primers targeting cats amplified horse ( $\mathrm{Ct} 37.2-$ 38.6), dog ( $\mathrm{Ct}$ 35.9-38.2), black rat ( $\mathrm{Ct} 38.0-38.2)$, chicken (Ct 34.8-35.2) and human (Ct 34.4-34.7) DNA; and the primers targeting humans amplified dog (37.1),

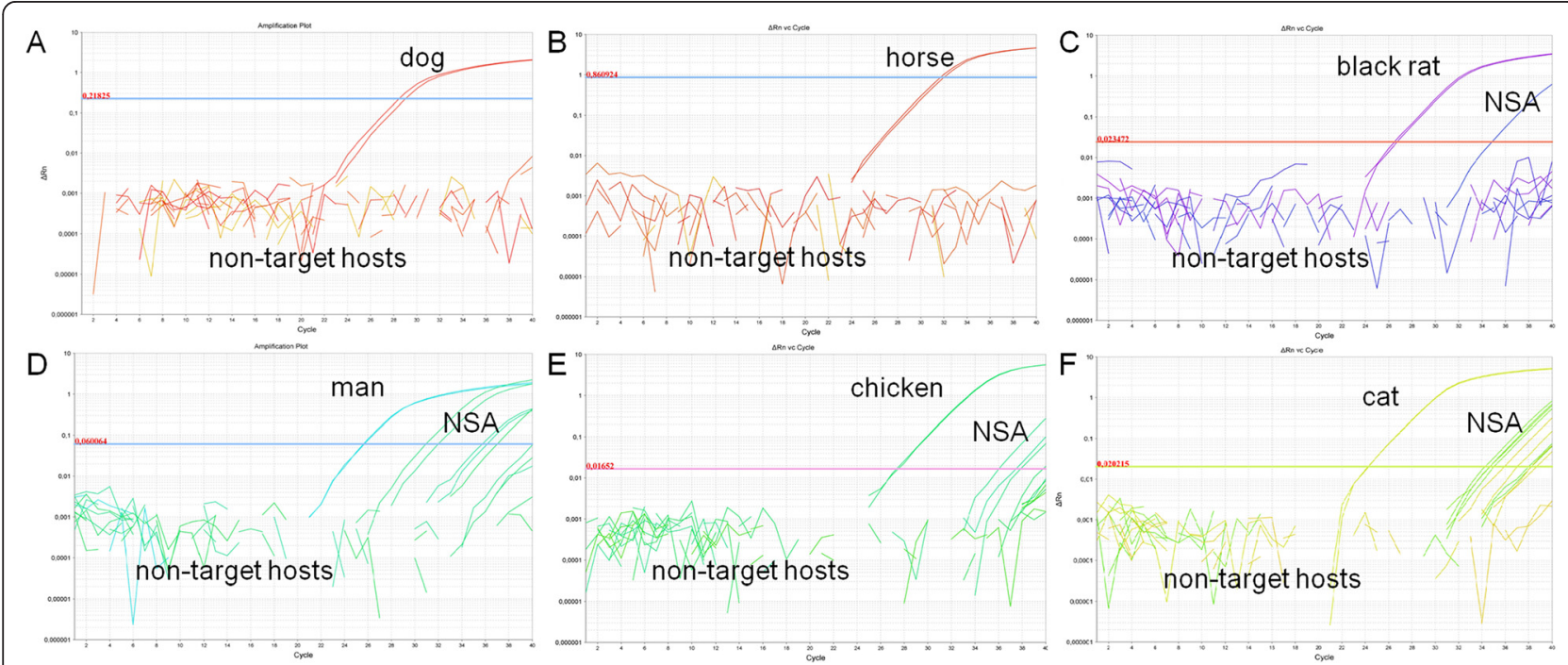

Figure 1 Specificity of the protocols. Specificity assays for each real time PCR protocol targeting different animal species: $\mathbf{A}$, dog; $\mathbf{B}$, horse; $\mathbf{C}$, black rat; D, man; $\mathbf{E}$, chicken; $\mathbf{F}$, cat. Non-specific amplifications (NSA) were determined by melt curve analysis and/or cutoff Ct value (for more details, see text). 
Table 2 Efficiency and detection limit

\begin{tabular}{lllll}
\hline Target host & Slope & $\mathbf{R}^{\mathbf{2}}$ & $\varepsilon$ (\%) & Detection limit (per 2 $\boldsymbol{\mu l})$ \\
\hline Dog & $-3.58 \pm 0.69$ & $0.93 \pm 0.10$ & $96.3 \pm 30.8$ & $1 \mathrm{pg}$ \\
Horse & $-3.88 \pm 0.61$ & $0.96 \pm 0.02$ & $83.28 \pm 14.74$ & $10 \mathrm{pg}$ \\
Cat & $-3.37 \pm 0.16$ & $0.93 \pm 0.02$ & $96.89 \pm 4.13$ & $1 \mathrm{pg}$ \\
Black rat & $-4.29 \pm 0.16$ & $0.94 \pm 0.04$ & $71.06 \pm 3.32$ & $1 \mathrm{pg}$ \\
Chicken & $-3.65 \pm 0.65$ & $0.96 \pm 0.06$ & $92.61 \pm 27.24$ & $10 \mathrm{pg}$ \\
Man & $-3.84 \pm 0.53$ & $0.83 \pm 0.23$ & $84.17 \pm 15.74$ & $100 \mathrm{fg}$ \\
\hline
\end{tabular}

Slope, $\mathrm{R}^{2}$, amplification efficiency, and detection limit of the assays.

cat (Ct 31.0-32.0), and black rat (Ct 35.7-36.1). However, the non-specific amplifications above occurred usually in later cycles and could be distinguished by the $\mathrm{Ct}$ value (above defined lower limit of detection of each corresponding assay) and/or by melt curve analysis (as compared to the standard). Moreover, the specificity of the assays was also confirmed by DNA sequence analysis, which showed high levels of sequence identity (96-100\%) with corresponding sequences available in GenBank (accession number: KJ185407.1, KF282339.1, KF964328.1, AB194817.1, KF038166.1, and KJ522809.1).

The detection limit of the assays ranged from $10 \mathrm{pg}$ to $100 \mathrm{fg}$, with an acceptable level of homogeneity among replicates and reaction efficiency (Table 2). Remarkably, time course experiments showed that the real time PCR assay targeting black rat DNA was capable of detecting small amounts of the host DNA ( $1 \mathrm{pg})$ up to $120 \mathrm{~h}$ after the blood feeding (Figure 2).

Among field-collected engorged female sand flies, 91\% were positive and $9 \%$ negative for any host DNA. In particular, $73 \%$ of them were fed on humans, $23 \%$ on chickens, $22 \%$ on dogs, $15 \%$ on horses, $11 \%$ on black rats and $2 \%$ on cats. Interestingly, most $L$. longipalpis females were fed on humans (76.1\%), followed by chickens (19.6\%), dogs (16.3\%), horses (16.3\%), black rats (12\%) and cats $(2.2 \%)$.

In total, $48 \%$ of the field-collected female sand flies were positive for one animal species, $31 \%$ for two and $12 \%$ for three. Among females that were fed on one source, the

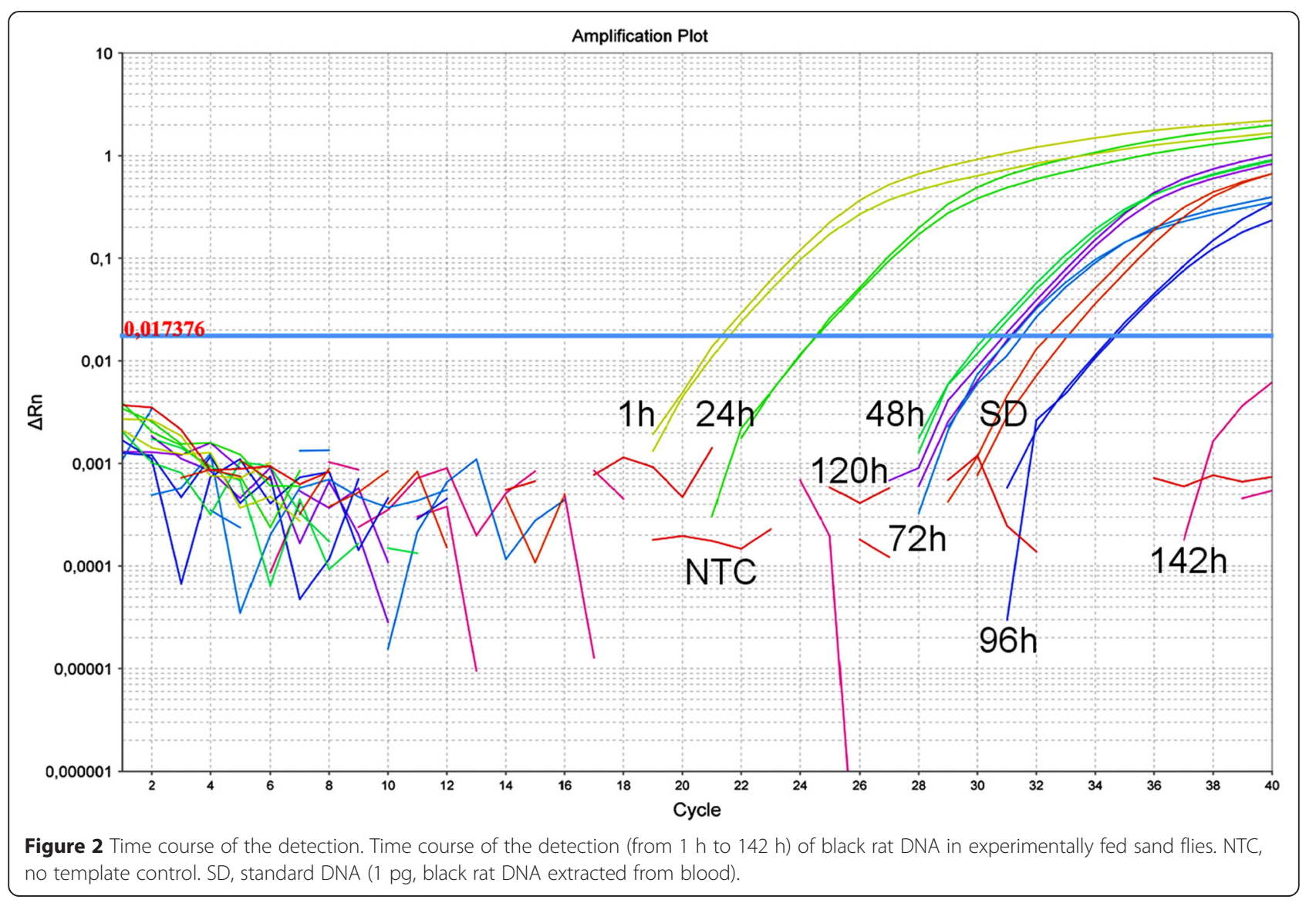


majority contained human blood (73\%), followed by chicken (10.4\%) and dog blood (6.2\%). Among those fed on two sources, most of them were positive for human + horse (7), human + chicken (7), human $+\operatorname{dog}(8)$ and human + rat (4). Finally, most females fed on three sources were positive for human $+\operatorname{dog}+$ chicken (5), followed by human + horse + rat (3), human $+\operatorname{dog}+$ cat (1), human + horse + chicken (1), and human + chicken + rat (1).

\section{Discussion}

In the present study we developed SYBR Green-based real time PCR assays for the identification of female sand fly blood meals. Remarkably, the assays were capable of detecting small amounts of host DNA in fieldcollected engorged females stored at $-20^{\circ} \mathrm{C}$ for $\sim 4$ years. The good performance of the assays developed herein allowed the detection of as little as $100 \mathrm{fg}$ per reaction mixture (i.e., $2 \mu \mathrm{l}$ ) of the host DNA (i.e., human). Indeed, the detection limit of our assays is fairly equivalent to that reported by some authors (10 pg in Ref. [10]; 1 pg in Ref. [21]), confirming the usefulness of the cytochrome $b$ gene as a genetic target for blood meal identification in sand flies, as previously demonstrated with conventional PCR protocols [21-24].

Several methodologies have been used to detect the blood meal in arthropod vectors, such as mosquitoes [17], but there are some biological differences that make it difficult to extrapolate the results for sand flies, including the lower amount of blood imbibed by sand flies ( $1 \mu \mathrm{l}$ or less) [25] than mosquitoes $(2-6 \mu \mathrm{l})$ [26]. Additionally, the blood digestion in haematophagous insects may result in DNA denaturation, therefore impairing the detection of the host DNA some days after the blood meal $[27,28]$. It is thus desirable to have a technique that is sensitive enough to allow the detection of minimal amounts of DNA, even some days after the ingestion of the blood. Indeed, it is difficult to estimate the time elapsed since the last blood meal, particularly in fieldcollected female sand flies with no visible blood in the abdomen. The results of time course experiments obtained herein demonstrated that the protocol targeting black rats allowed the detection of the host DNA up to 5 days after the blood feeding. This is consistent with other published assays for mosquito and sand fly blood meal identification, which generally were able to detect the host DNA for up to $1-4$ days [10,21,22,27-29]. Interestingly, a PCR heteroduplex assay was developed to identify avian derived mosquito blood meals, being capable of detecting the host DNA for up to 7 days [30]. The authors suggested that the greater amount of host DNA in the avian blood meal persists for a longer period than in a mammalian blood meal.

The catholic feeding behavior of L. longipalpis is well acknowledged [9]. Accordingly, most females belonging to this species analyzed in the current study were positive for humans, followed by chickens, dogs, horses, black rats and cats. Interestingly enough, most fieldcollected L. longipalpis females were trapped in chicken coops near human houses, being $19.2 \%$ of the human blood-positive females also positive for chicken blood. This data may suggest that the establishment of chicken coops near human houses may increase the risk of exposure to sand flies. Certainly, studying the blood feeding behaviour of sand fly vectors may help in understanding host-vector interactions and possibly the transmission dynamics of Leishmania parasites [31,32].

\section{Conclusions}

In conclusion, the SYBR Green-based real time PCR assays standardized herein represent promising tools for blood meal identification in field-collected sand flies. Indeed, these assays successfully detected small amounts of host DNA in female sand flies fed on different vertebrate species and, specifically for black rats, up to 5 days after the blood meal. As a perspective, it would be valuable to increase the efficiency of these assays for blood meal quantification purposes. Finally, from a cost-benefit perspective, a multiplex real time PCR assay should be standardized for the simultaneous detection of blood meals from different hosts in sand flies as well in other blood feeding arthropods. In this perspective, the use of TaqMan probes and, perhaps, designing new primers (e.g., for cats and humans) would be more appropriate to increase the specificity of the assay.

\section{Competing interests}

The authors declare that they have no competing interests.

\section{Authors' contributions}

Conceived and designed the experiments: KGSS, MPC and FDT. Performed the experiments: KGSS and RCSM. Contributed to sample collection: KGSS and PLC. Contributed to data interpretation: MPC, DO, SPBF and FDT. Wrote the paper: KGSS and FDT. All authors read and approved the final version of the manuscript.

\section{Acknowledgements}

Thanks to Maria Stefania Latrofa for her assistance with sequence editing and analysis and to Fernando José da Silva for his assistance with the sand flies. The first author (KGSS) received a Master's scholarship from Fundação de Amparo à Ciência e Tecnologia do Estado de Pernambuco (FACEPE). Thanks to Vice-Presidency of Education, Information and Communication (VPEIC) of Fiocruz for supporting this publication.

Received: 18 August 2014 Accepted: 3 April 2015

Published online: 16 April 2015

\section{References}

1. Maroli M, Feliciangeli MD, Bichaud L, Charrel RN, Gradoni L. Phlebotomine sandflies and the spreading of leishmaniases and other diseases of public health concern. Med Vet Entomol. 2013;27:127-47.

2. Ready PD. Factors affecting egg production of laboratory-bred Lutzomyia longipalpis (Diptera: Psychodidae). J Med Entomol. 1979;16:413-23.

3. Shaw JJ, Lainson R. Leishmaniasis in Brazil: II. Observations on enzootic rodent leishmaniasis in the lower Amazon region-the feeding habits of the vector, Lutzomyia flaviscutellata in reference to man, rodents and other animals. Trans R Soc Trop Med Hyg. 1968;62:396-405. 
4. Guy MW, Killick-Kendrick R, Gill GS, Rioux JA, Bray RS. Ecology of leishmaniasis in the south of France. 19. Determination of the hosts of Phlebotomus ariasi Tonnoir, 1921 in the Cévennes by bloodmeal analyses. Ann Parasitol Hum Comp. 1984;59:449-58.

5. Ngumbi PM, Lawyer PG, Johnson RN, Kiilu G, Asiago C. Identification of phlebotomine sandfly bloodmeals from Baringo District, Kenya, by direct enzyme-linked immunosorbent assay (ELISA). Med Vet Entomol. 1992;6:385-8.

6. Oliveira-Pereira YN, Moraes JL, Lorosa ES, Rebêlo JM. Feeding preference of sand flies in the Amazon, Maranhão State, Brazil. Cad Saude Publica. 2008;24:2183-6.

7. Baum M, Ribeiro MC, Lorosa ES, Damasio GA, Castro EA. Eclectic feeding behavior of Lutzomyia (Nyssomyia) intermedia (Diptera, Psychodidae, Phlebotominae) in the transmission area of American cutaneous leishmaniasis, state of Paraná, Brazil. Rev Soc Bras Med Trop. 2013;46:560-5.

8. Macedo-Silva VP, Martins DR, De Queiroz PV, Pinheiro MP, Freire CC, Queiroz JW, et al. Feeding preferences of Lutzomyia longipalpis (Diptera: Psychodidae), the sand fly vector, for Leishmania infantum (Kinetoplastida: Trypanosomatidae). J Med Entomol. 2014;51:237-344.

9. Lainson R, Rangel EF. Lutzomyia longipalpis and the eco-epidemiology of American visceral leishmaniasis, with particular reference to Brazil: a review. Mem Inst Oswaldo Cruz. 2005;100:811-27.

10. Haouas N, Pesson B, Boudabous R, Dedet JP, Babba H, Ravel C. Development of a molecular tool for a identification of Leishmania reservoir host by blood meal analysis in the vectors. Am J Trop Med Hyg. 2007;77:1054-9.

11. Nery LC, Lorosa NE, Franco AM. Feeding preference of the sand flies Lutzomyia umbratilis and L. spathotrichia (Diptera: Psychodidae, Phlebotominae) in an urban forest patch in the city of Manaus, Amazonas, Brazil. Mem Inst Oswaldo Cruz. 2004;99:571-4.

12. Afonso MM, Gomes AC, Meneses CR, Rangel EF. Studies on the feeding habits of Lutzomyia (N.) intermedia (Diptera, Psychodidae), vector of cutaneous leishmaniasis in Brazil. Cad Saude Publica. 2005;21:1816-20.

13. Fonteles RS, Vasconcelos GC, Azevêdo PC, Lopes GN, Moraes JL, Lorosa ES, et al. Blood feeding preference of Lutzomyia whitmani (Diptera, Psychodidae) in a transmission area for American cutaneous leishmaniasis in the State of Maranhão, Brazil. Rev Soc Bras Med Trop. 2009;42:647-50.

14. Rossi E, Bongiorno G, Ciolli E, Di Muccio T, Scalone A, Gramiccia M, et al. Seasonal phenology, host-blood feeding preferences and natural Leishmania infection of Phlebotomus perniciosus (Diptera, Psychodidae) in a high-endemic focus of canine leishmaniasis in Rome province, Italy. Acta Trop. 2008;105:158-65.

15. Afonso MM, Duarte R, Miranda JC, Caranha L, Rangel EF. Studies on the Feeding Habits of Lutzomyia (Lutzomyia) longipalpis (Lutz \& Neiva, 1912) (Diptera: Psychodidae: Phlebotominae) populations from endemic areas of American visceral leishmaniasis in Northeastern Brazil. J Trop Med. 2012;2012:858657.

16. Marassá AM, Galati EA, Bergamaschi DP, Consales CA. Blood feeding patterns of Nyssomyia intermedia and Nyssomyia neivai (Diptera, Psychodidae) in a cutaneous leishmaniasis endemic area of the Ribeira Valley, State of São Paulo, Brazil. Rev Soc Bras Med Trop. 2013;46:547-54.

17. Kent RJ. Molecular methods for arthropod bloodmeal identification and applications to ecological and vector-borne disease studies. Mol Ecol Resour. 2009:9:4-18.

18. Costa PL, Dantas-Torres F, da Silva FJ, Guimarães VC, Gaudêncio K, BrandãoFilho SP. Ecology of Lutzomyia longipalpis in an area of visceral leishmaniasis transmission in north-eastern Brazil. Acta Trop. 2013;126:99-102.

19. Young GD, Duncan MA. Guide to the identification and geographic distribution of Lutzomyia sand flies in Mexico, The West Indies, Central and South America (Diptera: Psichodidae). Mem Amer Ent Inst. 1994;54:1-881.

20. Too HP. Real time PCR quantification of GFR-2 alternatively spliced isoforms inmurine brain and peripheral tissues. Brain Res Mol Brain Res. 2003:114:146-54.

21. Abbasi I, Cunio R, Warburg A. Identification of bloodmeals imbibed by phlebotomine sand flies using cytochrome b PCR and reverse line blotting Vector Borne Zoonotic Dis. 2009;9:79-86.

22. Garlapati RB, Abbasi I, Warburg A, Poché D, Poché R. Identification of bloodmeals in wild caught blood fed Phlebotomus argentipes (Diptera: Psychodidae) using cytochrome b PCR and reverse line blotting in Bihar, India. J Med Entomol. 2012:49:515-21.

23. Tiwananthagorn S, Bhutto AM, Baloch JH, Soomro FR, Kawamura Y, Nakao R, et al. Zoophilic feeding behaviour of phlebotomine sand flies in the endemic areas of cutaneous leishmaniasis of Sindh Province, Pakistan. Parasitol Res. 2012;111:125-33.

24. Jiménez M, González E, Iriso A, Marco E, Alegret A, Fúster F, et al. Detection of Leishmania infantum and identification of blood meals in Phlebotomus perniciosus from a focus of human leishmaniasis in Madrid, Spain. Parasitol Res. 2013;112:2453-9.

25. Daba S, Daba A, Shehata MG, El Sawaf BM. A simple micro-assay method for estimating blood meal size of the sand fly, Phlebotomus langeroni (Diptera: Psychodidae). J Egypt Soc Parasitol. 2004;34:173-82.

26. Clements AN. The biology of mosquitoes: development structure and reproduction. 1st ed. London: Chapman \& Hall; 1992.

27. Kent RJ, Norris DE. Identification of mammalian blood meals in mosquitoes by a multiplexed polymerase chain reaction targeting cytochrome b. Am J Trop Med Hyg. 2005;73:336-42.

28. Sant'Anna MR, Jones NG, Hindley JA, Mendes-Sousa AF, Dillon RJ, Cavalcante $\mathrm{RR}$, et al. Blood meal identification and parasite detection in laboratory-fed and field captured Lutzomyia longipalpis by PCR using FTA databasing paper. Acta Trop. 2008;107:230-7.

29. Valinsky L, Ettinger G, Bar-Gal GK, Orshan L. Molecular identification of bloodmeals from sand flies and mosquitoes collected in Israel. J Med Entomol. 2014:51:678-85

30. Lee JH, Hassan H, Hill G, Cupp EW, Higazi TB, Mitchell CJ, et al. Identification of mosquito avian-derived blood meals by polymerase chain reaction heteroduplex analysis. Am J Trop Med Hyg. 2002;66:599-604.

31. Es-Sette N, Ajaoud M, Laamrani-Idrissi A, Mellouki F, Lemrani M. Molecular detection and identification of Leishmania infection in naturally infected sand flies in a focus of cutaneous leishmaniasis in northern Morocco. Parasit Vectors. 2014;7:305.

32. Maia C, Parreira R, Cristóvão J, Freitas F, Afonso M, Campino L. Molecular detection of Leishmania DNA and identification of blood meals in wild caught phlebotomine sand flies (Diptera: Psychodidae) from southern Portugal. Parasit Vectors. 2015;8:173.

\section{Submit your next manuscript to BioMed Central and take full advantage of:}

- Convenient online submission

- Thorough peer review

- No space constraints or color figure charges

- Immediate publication on acceptance

- Inclusion in PubMed, CAS, Scopus and Google Scholar

- Research which is freely available for redistribution 